\title{
DETERMINATION OF BLOOD ASCORBIC ACID
}

\author{
By M. PIJOAN AND F. KLEMPERER \\ (From the Department of Surgery, Peter Bent Brigham Hospital, and the Department of \\ Biochemistry, Harvard Medical School, Boston)
}

(Received for publication December 28, 1936)

Since vitamin $\mathrm{C}$ has definitely been identified with ascorbic acid the clinical importance of this substance has increased. However, the interpretation of blood ascorbic acid values has been uncertain, in part, because of the variations in values encountered in routine analyses. Tillmans, Hirsch and Hirsch (1) first developed the method of determining the presence of reduced ascorbic acid in serum. To make it clinically practical, this original method has been modified by Farmer and $A b t(2,3)$. Their procedure was to use metaphosphoric acid as a deproteinizing agent which had been introduced for this purpose by Fujita and Iwatake (4) and to determine the reduced ascorbic acid in the filtrate with 2:6 dichlorophenol indophenol (5).

Pijoan, Townsend and Wilson (6), in attempting to repeat the experiments of Farmer and Abt (2), noted a considerable loss of ascorbic acid in serum which had been allowed to stand at room or ice-box temperatures for over one hour. The loss of ascorbic acid from the time of withdrawal of the blood from the patient to its immediate analysis in the laboratory is incalculable. This loss is due to the oxidation of ascorbic acid. Barron, de Meio, and Klemperer (7) have pointed out that the oxidation can be achieved by catalysts such as copper or the hemochromogens. Barron, Barron and Klemperer (8) showed that the time required for half-oxidation of ascorbic acid added to serum was reduced by the addition of small amounts of copper. They further demonstrated the presence of a protecting mechanism in the serum against the oxidation of ascorbic acid by copper. This inhibitory substance has been shown by de Caro and Giani (9), Bersin, Köster and Jusatz (10) and Mawson (11) to be glutathione.

By the use of the Warburg apparatus in an atmosphere of 5 per cent $\mathrm{CO}_{2}$ and 95 per cent $\mathrm{O}_{2}$, Barron, Barron and Klemperer were able to show that the protection in serum against catalysts was not complete, the half-oxidation time requiring from 148 to 244 minutes. In ordinary laboratory glassware, using all the required precautions against contamination, and by using Tillmans' method of assay modified by Farmer and Abt, the half oxidation time was found to be about fifty minutes. This would seem to indicate that the ideal time for analysis would be at the time the blood is collected. Even at the $\mathrm{pH}$ of the metaphosphoric acid filtrate $(\mathrm{pH} 2)$ the oxidation of ascorbic acid by minute traces of copper is pronounced (8). This is shown by the oxidation of ascorbic acid in metaphosphoric acid (Figure 1).

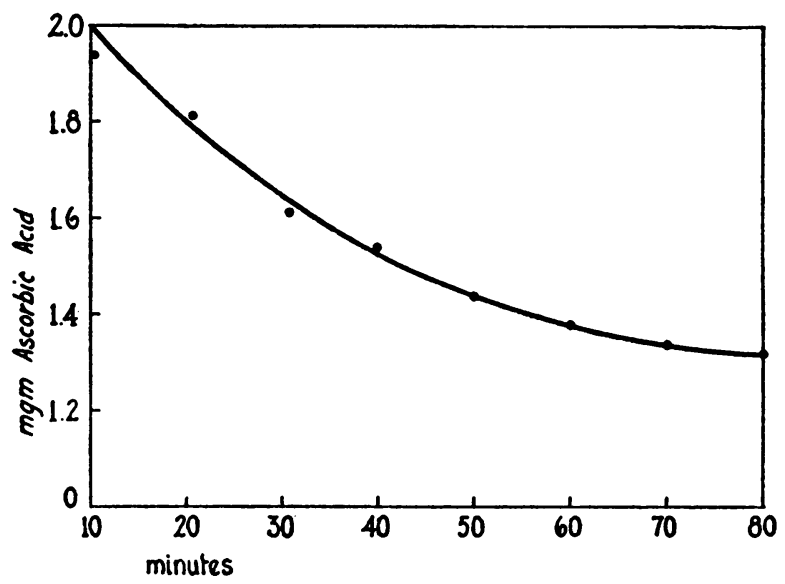

Fig. 1. Oxidation of Ascorbic Acid in Metaphosphoric Acid Filtrate. (No KCN.) Temperature. $25^{\circ} \mathrm{C}$.

Since KCN had been found to protect the oxidation of ascorbic acid in the serum by added copper and hemochromogens (8), we attempted to investigate its effect on the catalysts ordinarily present in blood. It must be further noted that copper is present in all biological fluids in a concentration sufficient to produce the oxidation of ascorbic acid (12). The following method can be used for the clinical determination of ascorbic acid in serum. 


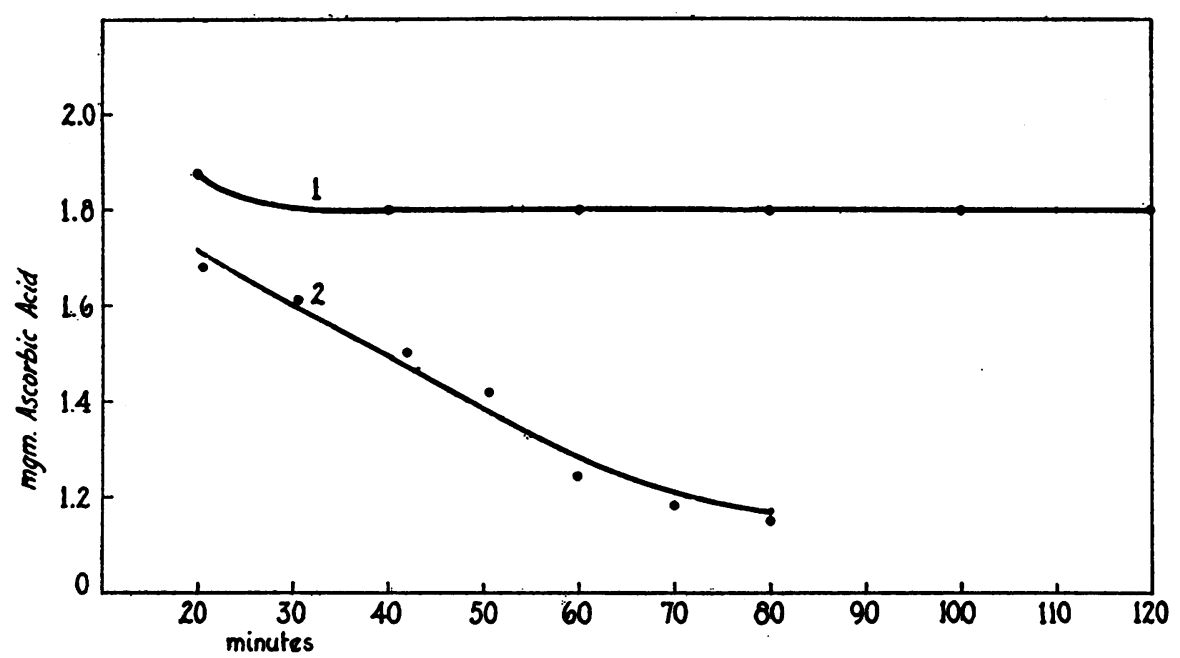

Fig. 2. Curve 1-Inhibition of Oxidation of Ascorbic Acid in Serum by KCN. Curve 2-Oxidation of Ascorbic Acid in Serum Without KCN.

For routine purposes $5 \mathrm{mgm}$. $\mathrm{KCN}$ and 10 mgm. of potassium oxalate are added to test tubes. Blood is collected from a patient's vein, usually fasting, and about 6 to $7 \mathrm{cc}$. are placed in the tube and centrifuged. Two cubic centimeters of plasma are transferred to a test tube or centrifuge tube. To this is added $2 \mathrm{cc}$. of distilled water and $6 \mathrm{cc}$. of 10 per cent metaphosphoric acid (the metaphosphoric acid is made up fresh daily). This mixture is stirred rapidly with a glass rod for thirty seconds and allowed to stand for three minutes. In order to separate the protein precipitate from the protein-free fluid, either filtration through a Whatman 42 filter paper or centrifuging is satisfactory. Two cubic centimeters of either the filtrate or the supernatant fluid is used for the determination. This fluid is placed in a beaker $(50 \mathrm{cc}$.) for titration with $2: 6 \mathrm{di}$ chlorophenol indophenol. Titrations to a pink end-point are carried out using a light with a daylight filter. A $1 / 1000$ Molar solution (29 $\mathrm{mgm}$. of dye in $100 \mathrm{cc}$. of water) is the most efficient for this purpose. In preparing the dye solution it is convenient to dissolve it in water heated to $85^{\circ} \mathrm{C}$., shake for fifteen minutes and filter if necessary. The dye is standardized against ascorbic acid (Hoffman-Roche). For purposes of convenience and simplicity the following calculation is included.

$\begin{gathered}\text { cc. of dye used } \\ \text { in titration }\end{gathered} \times \frac{.001 \times 176 \times 100}{0.4}=$

cc. dye used $\times 44=$ mgm.

ascorbic acid per $100 \mathrm{cc}$. plasma.
0.001 is the concentration of the dye in millimols per cubic centimeter.

176 is the milligrams of ascorbic acid equivalent to 1 millimol.

0.4 is the amount of serum used for the titration.

The whole is multiplied by 100 to give the results in terms of $100 \mathrm{cc}$. of plasma.

The error in the titration amounts to $\pm 0.1 \mathrm{mgm}$.

The addition of ascorbic acid to serum in which the ascorbic acid value was previously determined yields recovery values as expressed in Table $I$.

TABLE I

Recovery of ascorbic acid added to serum containing $K C N$ 100 milligrams per 100 cubic centimeters of serum

\begin{tabular}{|c|c|c|c|c|c|c|}
\hline \multicolumn{2}{|c|}{$\begin{array}{c}\text { Originally } \\
\text { present }\end{array}$} & $\begin{array}{c}\text { Amount } \\
\text { added }\end{array}$ & $\begin{array}{l}\text { Theo-- } \\
\text { retical } \\
\text { total }\end{array}$ & $\begin{array}{l}\text { Found } \\
\text { after } 15 \\
\text { minutes }\end{array}$ & $\begin{array}{l}\text { After } \\
\text { hour }\end{array}$ & $\begin{array}{l}\text { After } \\
1 \text { hour }\end{array}$ \\
\hline $\begin{array}{l}1 \\
2 \\
3 \\
4 \\
5 \\
6 \\
7 \\
8 \\
9\end{array}$ & $\begin{array}{c}m g m . \\
.86 \\
.87 \\
.86 \\
.86 \\
.86 \\
.86 \\
.86 \\
.86 \\
.86\end{array}$ & $\begin{array}{r}\text { mgm. } \\
5.0 \\
4.0 \\
3.0 \\
2.0 \\
2.0 \\
1.5 \\
1.5 \\
1.0 \\
1.0\end{array}$ & $\begin{array}{l}\text { mgm. } \\
5.86 \\
4.87 \\
3.86 \\
2.86 \\
2.86 \\
2.36 \\
2.36 \\
1.86 \\
1.86\end{array}$ & $\begin{array}{c}\text { mgm. } \\
5.80 \\
4.80 \\
3.84 \\
2.84 \\
2.84 \\
2.30 \\
2.28 \\
1.84 \\
1.84\end{array}$ & $\begin{array}{c}m g m . \\
5.80 \\
4.80 \\
3.83 \\
2.84 \\
2.82 \\
2.30 \\
2.28 \\
1.82 \\
1.84\end{array}$ & $\begin{array}{c}m g m . \\
5.80 \\
4.78 \\
3.83 \\
2.84 \\
2.82 \\
2.28 \\
2.28 \\
1.82 \\
1.84\end{array}$ \\
\hline
\end{tabular}

With this method we have obtained values varying from 0.65 to $2.00 \mathrm{mgm}$. per cent in the blood plasma of 150 normal individuals.

\section{CONCLUSION}

In assaying ascorbic acid by $2: 6$ dichlorophenol indophenol there is a considerable loss of ascorbic 
acid due to oxidation, which can be prevented by the use of KCN for preservation of the blood.

\section{BIBLIOGRAPHY}

1. Tillmans, J., Hirsch, P., and Hirsch, W., Das Reduktionsvermögen pflanzlicher Lebensmittel und seine Beziehung zum Vitamin C; der reduzierende Stoff des Citronensaftes. Ztschr. f. Untersuch. d. Lebensmitt., 1932, 63, 1.

2. Farmer C. J., and Abt., A. F., Ascorbic acid content of blood. Proc. Soc. Exper. Biol. and Med., 1935, 32, 1625

3. Farmer, C. J., and Abt., A. F., Determination of reduced ascorbic acid in small amounts of blood. Proc. Soc. Exper. Biol. and Med., 1936, 34, 146.

4. Fujita, A., and Iwatake, D., Über die Bestimmung von Vitamin C mittels 2, 6-Dichlorphenol-indophenol. Biochem. Ztschr., 1935, 277, 293.

5. Cohen, B., Gibbs, H. D., and Clark, W. M., Studies on oxidation-reduction; preliminary study of indophenols. Public Health Rep., 1924, 39, 804.

6. Pijoan, M., Townsend, S. R., and Wilson, A., De- termination of reduced ascorbic acid in blood. Proc. Soc. Exper. Biol. and Med., 1936, 35, 224.

7. Barron, E. S. G., de Meio, R. H., and Klemperer, F., Studies on biological oxidations. V. Copper and hemochromogens as catalysts for the oxidation of ascorbic acid. The mechanism of the oxidation. J. Biol. Chem., 1936, 112, 625.

8. Barron, E. S. G., Barron, A. G., and Klemperer, F., Studies on biological oxidations. VII. The oxidation of ascorbic acid in biological fluids. J. Biol. Chem. (In press, 1936.)

9. de Caro, L., and Giani, M., Oxydationsschutz der Ascorbinsäure durch tierisches Gewebe. Ztschr. f. physiol. Chem., 1934, 228, 13.

10. Bersin, T., Köster, H., and Jusatz, H. J., Biochemische Beziehungen zwischen Ascorbinsäure und Glutathion. Ztschr. f. physiol. Chem., 1935, 235, 12.

11. Mawson, C. A., Influence of animal tissues on oxidation of ascorbic acid. Biochem. J., 1035, 29, 569.

12. Lindow, C. W., Elvehjem, C. A., and Peterson, W. H., The copper content of plant and animal foods. J. Biol. Chem., 1929, 82, 465. 